\title{
Case Study Gastro-Intestinal Fistula Nutritional Support 品器
}

\author{
Gertrudis Adrianza de Baptista* \\ Universidad Central de Venezuela-Hospital Universitario de Caracas, Venezuela
}

Received: May 31, 2018; Published: June 18, 2018

*Corresponding author: Gertrudis Adrianza de Baptista, Titular Professor, Universidad Central de Venezuela-Hospital Universitario de Caracas, Venezuela

Keywords: Somatostatine Therapy; Sheldon's Therapeutic Plan; Biliary Lithiasys; Laparotomy; Infrarenal vena; Sigmoid Injury; Vena Cava Repair; Ferrada procedure; Colecistectomy; Hartman's Pouch; Bogotas Pouch; Benutrex; Ampoule; Malnutrition

Abbrevations: TPN: Total Parenteral Nutrition; HBP: High Blood Pressure; DM: Diabetes Mellitus; CHD: Coronary Heart Disease; GGCs: Good General Conditions

\section{Introduction}

"When a fistula is developed the tendency is first not to do anything and see how serious it will get; and therefore, at the time the catastrophe's total impact strikes, the patient is already septic, nutritionally depleted and presenting an extensive cutaneous destruction" Chapman [1]. Nutritional management is one of the most important factors when successfully treating gastro-intestinal fistulas Ellis H [2]. In 21 years of experience at the Caracas University Hospital's (HUC) Nutritional Support Unit (NSU) Belloso R, Baptista GA, Souchon E [3]. It has been possible to confirm that employing exclusively nutritional support or nutrition therapy, there are more possibilities of fistulas closure that if employing combinations of nutritional support and surgery; or to the contrary, only surgery - of those fistulas that are not of surgical closing -, this being also proven by other authors [3]. As to the kind of nutritional support, in each of the above cited treatment modalities, Total Parenteral Nutrition (TPN) prevails upon Enteral (E) and mixed Nutrition (N) as nutritional therapeutic measure to achieve the closing of fistulas Fukuchi S et al. [4]. The use of this TPN nutritional support measure is more relevant in high grade fistulas difficult to access via catheter, as well as when fistulas are placed in the small Intestine complicated with dysfunctional gastro-intestinal tract Rombeau J Caldwell [5]. It is also important to notice that the Mortality Rate has significantly diminished from $40-65 \%$ down to $5-20 \%$, knowing that the majority of deaths are associated to malnutrition and sepsis Tulsyan et al. [6].

The managing of fistulas is oriented onto 4 stages described by Sheldon et al. [7].

a) Reanimation and skin protection;

b) Instituting nutritional handling; c) Evaluation and treatment, and

d) Sheldon's Therapeutic Plan.

And as for pharmacology managing, the use of somatostatine and analogues-octreotide-has been proposed in order to diminish fistulas output Alvarez et al. [8]. It is known that combining somatostatine therapy with TPN, allows $77 \%$ of fistulas closure within a 5 to 8 days time period Nubiola [9], facilitating high output fistulas' management. Somatostatine must be suspended if in 48 hours there is no decrease in the fistula output, or if in the next two or three weeks of treatment, there is no response. Normally, treatment with somatostatine analogues is well tolerated by the patient; however, some authors describe some complications from employing analogues such as nausea, cramps, and diarrheas as secondary effects, mainly at the start of treatment or upon dose increase. Biliary lithiasys has also been described during lengthy treatments as a result of the gallbladder's decrease motility [9].

\section{Objectives}

To early identify gastro-intestinal fistulas in order to establish as an interdisciplinary team an assertive nutritional treatment that allows diminishing its output and facilitates the spontaneous and/or surgical closure thereof. To improve the nutritional and metabolic status depletion associated to gastro-intestinal fistulas, and thus, improve prognosis. To diminish morbidity-mortality associated to the development of gastrointestinal fistulas by means of establishing nutritional managing protocols.

\section{Current Illness}

Case study: male patient, 35 years of age, afro-Venezuelan, a working man, original and coming from the Petare Parish of the 
Miranda State, Bolivarian Republic of Venezuela, who initiates current illness on August 27, 2006, upon ER admission at the Caracas University Hospital (HUC) for Gun Shut Wound (GSW), with three (3) incoming bullet-wounds (left lower quadrant, right lumbar and right gluteus).

\section{Case Study}

\section{Personal History}

He denies High Blood Pressure (HBP), Diabetes Mellitus (DM) and being allergic to medications.

\section{Family History}

a) Mother: Alive, 80 years old; HBP.

b) Father: Deceased from a Coronary Heart Disease (CHD) at 80 years of age.

c) Brothers: 8 brothers; 6 alive with no significant medical history and 2 deceased: CHD and MBA.

d) Sons: 2 alive and apparently in good health

\section{Psyco-Biological Habits}

a) Coffee: 1 cup a day up to August, 2006 (avoided due to gastritis)

b) Tobacco: Since he was 5years old, up to Current Illness's start (1 package/day = 18artons $/$ year).
c) Alcohol: heavy drinker
d) Illicit Drugs: no use of illicit drugs
e) Sleep: irregular; 6-7hours/day Admission

\section{Physical Examination}

Hemodynamically unstable with low blood pressure, tachycardia and rigid abdomen. A supra- and infra- umbilical exploratory Laparotomy was performed with the following findings and procedures:

\section{Findings}
a) Infrarenal vena cava injury
b) Duodenum's $1^{\text {st }}$ and $2^{\text {nd }}$ portions injury
c) Gallbladder injury
d) Sigmoid injury

\section{Procedures}

a) Vena cava repair

b) Ferrada procedure (pyloric gastroduodenostomy and jejunostomy

c) Colecistectomy

d) Left colostomy and Hartman's pouch

e) Bogotas pouch.

Two days after admission $(08 / 29 / 06)$, the patient is evaluated by the HUC Nutritional Support Unit (NSU) in order to establish nutritional diagnosis and treatment planning. As for Global
Subjective Valuation (GSV) the patient is classified B (Moderate Malnutrition) and anthropometrically, the following data was obtained: Weight $62 \mathrm{Kg}$; Size $1.78 \mathrm{~m}$; Ideal weight: $69 \mathrm{Kg}$; Usual weight $65 \mathrm{Kg}$; CMB $25.2 \mathrm{~cm}$ and PTr $5.4 \mathrm{~mm}$, all of which establishes the nutritional diagnosis of normal-weight according to Body Mass Index $(19,5 \mathrm{Kg} / \mathrm{mt} 2$ - WHO, 1998). His Total Caloric Requirement was calculated in $2200 \mathrm{Kcal}$ (35Kcal / Kg of current weight) and a progressive Hyper caloric Nutritional high protein Plan was implemented (due to hyper catabolism and severe malnutrition risk) starting Enteral Nutrition through jejunostomy (placed during surgery (08/27/06) together with 500 cc polymeric formula. The medic-pharmacological treatment implemented included: Parenteral Hydration (PH) 2000cc 0.45\% saline solution alternated with $0.9 \%$ at $60 \mathrm{cc}$ per/hour; KCI $20 \mathrm{mEq}$ in bottle 1 and 3; and one (1) IV Benutrex区 ampoule diluted in $0.45 \%$ saline solution, once a day (DO). From blood work values of 08/29/06, the patient presented anemia, leukocytosis with neutrophyle, moderate hypoalbuminemia, hyperchloremia, hypophosfatemia and hypomagnesemia (Table 1).

Table 1.

\begin{tabular}{|c|c|}
\hline \multicolumn{2}{|c|}{ Identification Data } \\
\hline Sex: Male & $\begin{array}{c}\text { Instruction Grade: Bachelor (High } \\
\text { School) }\end{array}$ \\
\hline Age/Race: 35; Afro-Venezuelan & Occupation: Workman \\
\hline $\begin{array}{c}\text { Place of Birth: Miranda State - } \\
\text { Vzla. (Capital Region) }\end{array}$ & Coming from: Miranda State -Vzla. \\
\hline \multicolumn{2}{|c|}{ Social Stratification: Graffar V (extreme poverty) } \\
\hline
\end{tabular}

On August 30, 2006, still with opened abdomen was taken to Operating Room(OR) for peritoneal lavage, presenting evidence of abundant bile and numerous adhesions, in addition to changing Bogota's pouch. Thereafter, on September 3, 2006, he is taken again to OR for peritoneal lavage, with the following findings: Sub-hepatic abscess with functioning duodenostomy, gastroand jejunostomy. On 09/04/07 after 5 days of ineffective enteral nutritional support and in absence of central access due to the jejunostomy and the recurrent peritoneal lavage, a $1015 \mathrm{Kcal}$ intake Peripheral Parenteral Nutrition is administered, and enteral intake maintained by jejunostomy (incremented up to $1000 \mathrm{Kcal}$ ), receiving a total of "2015 Kcal/day", all translating into 38Kcal per kilogram of current weight. On September $15^{\text {th }}$, he is taken again to $\mathrm{OR}$ for more peritoneal lavage, finding severe adherences and a clean peritoneal cavity, performing the following procedures: lyses of adhesions, peritoneal larvae and Bogotá pouch's removal, and retention sutures for abdomen's closure. It is worth highlighting that the nutritional support via ejunostomy indicated since the first evaluation by the NSU $(08 / 29 / 06)$, was not constant due to the multiple surgical interventions, not covering the patient's goal requirement $(2200 \mathrm{Kcal})$, reason for which he suffered a weight loss quantified in $9 \mathrm{Kg}$ in a month-time since admission, to weigh $52 \mathrm{Kg}$ up to day 09/27/06, with a Severe Acute Malnutrition nutritional diagnosis and GSV: C. At that time, jejunostomy (already dysfunctional) is removed and the following Nutritional Plan implemented: to maintain peripheral Parenteral Nutritional Support $(1100 \mathrm{Kcal})$ - he is on his $29^{\text {th }}$ day PPN since admission -, 
in addition to enteral supplementation with $500 \mathrm{Kcal}$ of polymeric formula, and the start of a (600Kcal) Full Liquid Oral Diet for a total intake of $2200 \mathrm{Kcal}$ (49Kcal per kilogram of current weight) (Table 2).

Table 2: Hematologic Parameters.

\begin{tabular}{|c|c|c|c|}
\hline PARAMETERS & VALUES & PARAMETERS & VALUES \\
\hline $\begin{array}{c}\text { HGB } \mathrm{n} / \mathrm{mm} 3 \mathrm{x} \\
10.000\end{array}$ & $(11.4)$ & Albumin g/Dl & $(2.5)$ \\
\hline Hcto Vol \% & $(34.9)$ & Globulins g/dL & $(2.3)$ \\
\hline WBC mm3 & $(18.800)$ & Uric acid mg/dL & - \\
\hline $\begin{array}{c}\text { Neutrophyles } \\
\%\end{array}$ & $(91.7)$ & $\begin{array}{c}\text { Cholesterol } \\
\mathrm{mg} / \mathrm{dL}\end{array}$ & - \\
\hline $\begin{array}{c}\text { Lymphocytes } \\
\%\end{array}$ & $(5.6)$ & $\begin{array}{c}\text { Triglycerides } \\
\mathrm{mg} / \mathrm{dL}\end{array}$ & - \\
\hline $\begin{array}{c}\text { CTL } \mathrm{mm}^{3} \\
\text { PLT } 10 \mathrm{~mm} \mathrm{~m}^{3}\end{array}$ & $(1052.8)$ & $\mathrm{Na}+\mathrm{mmol} / \mathrm{L}$ & $(140)$ \\
\hline $\begin{array}{c}\text { Glycemia mg/ } \\
\mathrm{dL}\end{array}$ & $(90)$ & $\mathrm{K}+\mathrm{mmol} / \mathrm{L}$ & $(4.2)$ \\
\hline Urea $\mathrm{mg} / \mathrm{dL}$ & $(24)$ & $\mathrm{mmol} / \mathrm{L}$ & $(110)$ \\
\hline Corrected: $(8.5)$ & $(0.75)$ & $\begin{array}{c}\text { Phosphorus } \\
\mathrm{mg} / \mathrm{dL}\end{array}$ & $(2.6)$ \\
\hline $\begin{array}{c}\text { Creatinine mg/ } \\
\mathrm{dL}\end{array}$ & $(4.8)$ & $\begin{array}{c}\text { Magnesium } \\
\mathrm{mg} / \mathrm{dl}\end{array}$ & $(1.8)$ \\
\hline \begin{tabular}{c} 
Proteins T. g/dL \\
\hline
\end{tabular} & & \\
\hline
\end{tabular}

Table 3: Laboratory Values 09/25/06.

\begin{tabular}{|c|c|c|c|}
\hline PARAMETERS & VALUES & PARAMETERS & VALUES \\
\hline $\begin{array}{c}\text { HGB } \mathrm{n} / \mathrm{mm} 3 \mathrm{x} \\
10.000\end{array}$ & $(11)$ & Albumin g/dL & $(2.9)$ \\
\hline Hcto $\mathrm{Vol} \%$ & $(33.5)$ & Globulins g/dL & $(3.4)$ \\
\hline WBC mm3 & $(16.100)$ & Uric acid mg/dL & $(3.0)$ \\
\hline $\begin{array}{c}\text { Neutrophyles } \\
\%\end{array}$ & $(83)$ & $\begin{array}{c}\text { Cholesterol mg/ } \\
\mathrm{dL}\end{array}$ & $(75)$ \\
\hline $\begin{array}{c}\text { Lymphocytes } \\
\%\end{array}$ & $(9.9)$ & $\begin{array}{c}\text { Triglycerides } \\
\mathrm{mg} / \mathrm{dL}\end{array}$ & $(151)$ \\
\hline $\begin{array}{c}\text { CTL mm3 } \\
\text { PLT } 10 \mathrm{~mm} 3\end{array}$ & $(1594)$ & $\mathrm{Na}+\mathrm{mmol} / \mathrm{L}$ & $(131)$ \\
\hline Glycemia mg/dL & $(125)$ & $\mathrm{K}+\mathrm{mmol} / \mathrm{L}$ & $(4.6)$ \\
\hline Urea $\mathrm{mg} / \mathrm{dL}$ & $(20)$ & Calcium mg//L & $(98)$ \\
\hline Creatinine mg/dL & $(0.64)$ & Phosphor mg/dL & $(8.6)$ \\
\hline Proteins T. g/dL & $(6.3)$ & $\begin{array}{c}\text { Magnesium mg/ } \\
\mathrm{dl}\end{array}$ & - \\
\hline
\end{tabular}

On October 2, 2006, the patient tolerates oral feeding, with a quantified weight recuperation of $1 \mathrm{Kg}$ (in 5 days as from oral diet start), being under metabolic and hydro electrolytic control, reason enough for progressing onto a Mechanically Soft-Food Diet (1700Kcal), low in residues with pro-biotic, maintaining enteral supplementation with polymeric formula (500Kcal), all of which contributes to a total of $2200 \mathrm{Kcal} /$ day $(42 \mathrm{Kcal} / \mathrm{Kg}$ of current weight); and on that same day, Peripheral Nutritional Support was discarded. On 10/05/06 the patient is in Good General Conditions, tolerating oral diet well, with no gastrointestinal symptoms, advancing to Full Diet (2300Kcal) contributing with 43Kcal per kilogram of current weight. The next day, the patient is discharged with closed abdomen and functioning colostomy. At the time of release, the patient presents a quantified $1.5 \mathrm{Kg}$ in 9days weight gain, weighing $53.5 \mathrm{Kg}$, with the following complementary values (Table 3). 4 months upon discharge, the patient was readmitted on February 07, 2007 due to evisceration, and taken to the operating room (OR) abdominal wall closure, to be later discharged again on the $9^{\text {th }}$ of the same month in Good General Conditions (GGCs) that he enjoys up to March 2, 2007 (25days later), when he presented fecaloid contents spillage out from the surgical wound.

\section{Admission Diagnosis: Colocutaneous Fistula}

Upon physical examination the patient presents: HR78bpm; RR16rpm. Skin: Well hydrated, of normal color. Neck: Symmetric carotid heartbeats; there are no pathologic lymph nodes, nor other pathologic signs. Thorax: Ample, eupeptic, breath sounds and regular heart sounds. Abdomen: Soft, non tender, no visceromegaly; ventral hernia at lower abdomen, outer fistula-like orifice at supraumbilical level with way out of dense fecal contents; functional colostomy in left lower quadrant; peri-fistular epidermolisis with plenty granulation tissue. Genitals: Normal. Extremities: No edema or injuries. Neurological: Conscious, oriented; preserved sensing. The patient's admission diagnosis is based as per the kind of secretion on the exit of fecal contents through the surgical wound. Subsequently, on 03/14/07, the diagnosis was confirmed by iodine contrasting fistulogram (Figure 1). According to Schwartz [10], there exist other methods for fistula diagnoses in addition to Fistulogram-X-Ray and among them highlight diverse clinic and Para-clinic elements such as:

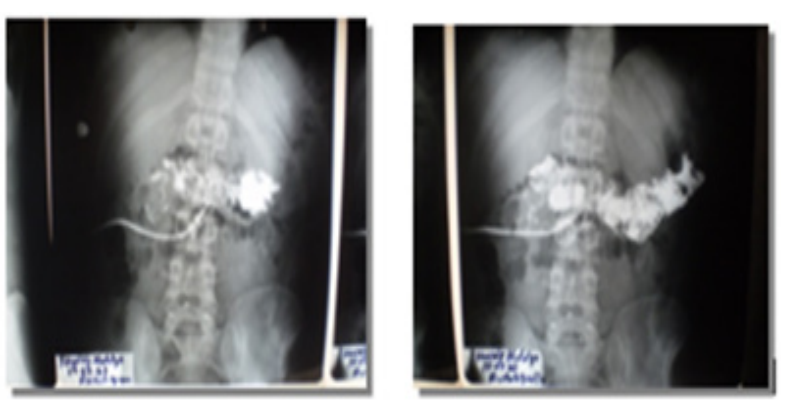

Figure 1: The patient's admission diagnosis.

a) Less Reliable Colorants Test (Phenol-red, carmine)

b) Operative wound secretion ( $1^{\text {st }}$ week after operation)

c) Echogram, Axial Computerized Tomography, Radiography, upper GI series, ERCP, small bowels series, barium enema; Intravenous pyelogram (IVP).

d) GI tract X-Ray series.

e) Endoscopies: Gastro-duodenal; Colonic

f) Abdominal Ultrasound

g) MRI

h) Clinic: Pain (localized or diffuse), abdominal distension, fever, tachycardia, vomit, intestinal obstruction. 
The denomination fistula is given to the abnormal communication between two surfaces. According to Schwartz [10], fistulas could be classified in

Etiologically (from less to more often) in spontaneous those and due to surgical traumas. Fistulas may also be classified as to the kind of communication between 2 viscera, or between viscera and abdominal wall in: internal and external (enteroatmospheric) ,respectively. Simple: Single small orifice of easy handling; or in Complex ones when it is difficult to manage for featuring multiple orifices, and are of difficult recollection. Per output: high ( $>500 \mathrm{cc} / 24$ hours), moderate (200 to 500cc/24hours) and low $(<200 \mathrm{cc} / 24 \mathrm{hours})$. Based on the previously stated qualifications, at the time of admission the Colocutaneous Fistula developed by the patient (for fecaloid output) is of surgical origin, extern, complex and of low output (<20cc/24hours).

\section{Nutritional Evolution}

From admission date on $03 / 02 / 07$, there does not exist documented nutritional diagnosis in the patient's medical history, presenting scarce fistula output (< de 20cc soft feces), in addition to the following anthropometric data obtained from the history: Postoperative was managed with Absolute Diet until the next day 03/03/07 (date of NSU) when according to medic orders oral diet was indicated in conjunction with a low residues diet to contribute $1800 \mathrm{Kcal}$ (30Kcal/Kg of current weight), since Colocutaneous Fistulas are not necessarily in contraindication with oral feeding. Medically and Pharmacologically was managed with: Parenteral Hydration (PH) $0.45 \% 2000 \mathrm{cc}$ alternated with $0.9 \%$ saline solution at $60 \mathrm{cc}$ per/hour; 1 and $3 \mathrm{KCl} 20 \mathrm{mEq}$ in bottle; one (1) Benutrex Intravenous (IV) dose dissolved in 0.45 solution, once a day, and Ranitidine 50mg (IV) every 8hours (Tables 4 \& 5).

Table 4: Laboratory Values

\begin{tabular}{|c|c|c|c|}
\hline Parameters & Values & Parameters & Values \\
\hline $\begin{array}{c}\text { HGB } / \mathrm{mm} 3 \mathrm{x} \\
10.000\end{array}$ & $(11.5)$ & Albumin g/dL & $(3.2)$ \\
\hline Hcto Vol \% & $(34.0)$ & Globulins g/dL & $(3.7)$ \\
\hline WBC mm3 & $(9.200)$ & Uric acid mg/dL & - \\
\hline Neutrophyles \% & $(70.2)$ & Cholesterol mg/dL & - \\
\hline Lymphocytes \% & $(14.4)$ & Triglycerides mg/dL & - \\
\hline CTL mm3 & $(1325)$ & Na+ mmol/L & $(138)$ \\
\hline PLT $10 \mathrm{~mm} 3$ & $(415)$ & $\mathrm{K}+\mathrm{mmol} / \mathrm{L}$ & $(4.2)$ \\
\hline Glycemia mg/dL & $(92)$ & $\mathrm{Cl}-\mathrm{mmol} / \mathrm{L}$ & $(102)$ \\
\hline Urea $\mathrm{mg} / \mathrm{dL}$ & $(21)$ & Calcium mg/dL & - \\
\hline Creatinine mg/dL & $(0.71)$ & Phosphor mg/dL & - \\
\hline Proteins T. g/dL & $(6.9)$ & Magnesium mg/dl & - \\
\hline
\end{tabular}

Table 5: Anthropometric Data.

\begin{tabular}{|c|c|}
\hline Weight & $61 \mathrm{Kg}$ \\
\hline Size & $1,78 \mathrm{~m}$ \\
\hline IMC & $19,25 \mathrm{Kg} / \mathrm{m}^{2}$ \\
\hline
\end{tabular}

The following results were observed from the Laboratory Values of day $03 / 03 / 07$

On $03 / 20 / 07$, the patient is evaluated by the Clinic Nutrition
Service from the Caracas University Hospital's Nutrition and Dietetics Department, obtaining the following anthropometric data: On the preceding 24hours Nutrition Record, the patient presented an approximately $1800 \mathrm{Kcal} /$ day consume. At the time was considered as nutritional diagnosis: Patient with severe weight loss, reason to indicate $2000 \mathrm{Kcal}$ Hyper-caloric, Hyper-protein low residue Diet (1.5g/Kg/current weight), distributed in 3 main meals and 2 afternoon snacks, jointly with Enteral supplementation of polymeric formula (250Kcal) which would contribute with the total of 2250 $\mathrm{Kcal} /$ day (37Kcal/Kg current weight). As for the VSG, it was qualified as B (Moderate Malnutrition). The patient maintains a colocutaneous fistula output below 20cc/day (Tables 6 \& 7).

Table 6: Laboratory Values.

\begin{tabular}{|c|c|c|c|}
\hline Parameters & Values & Parameters & Values \\
\hline $\begin{array}{c}\text { HGB n/mm3 x } \\
10.000\end{array}$ & $(13.5)$ & Albumin g/dL & - \\
\hline Hcto Vol \% & $(41.3)$ & Globulins g/dL & - \\
\hline WBC mm3 & $(5.200)$ & Uric acid mg/dL & - \\
\hline Neutrophyles \% & $(35.2)$ & Cholesterol mg/dL & - \\
\hline Lymphocytes \% & $(45.3)$ & Triglycerides mg/dL & - \\
\hline CTL mm3 & $(2356)$ & $\mathrm{Na}+\mathrm{mmol} / \mathrm{L}$ & $(141$ \\
\hline PLT $10 \mathrm{~mm} 3$ & $(223)$ & $\mathrm{K}+\mathrm{mmol} / \mathrm{L}$ & $(4.2$ \\
\hline Glycemia mg/dL & $(71)$ & $\mathrm{Cl}-\mathrm{mmol} / \mathrm{L}$ & $(106)$ \\
\hline Urea $\mathrm{mg} / \mathrm{dL}$ & $(37)$ & Calcium mg/dL & - \\
\hline Creatinine mg/dL & $(0.77)$ & Phosphor mg/dL & - \\
\hline Proteins T. g/dL & - & Magnesium mg/dl & $(1.6)$ \\
\hline
\end{tabular}

Table 7: The following anthropometric data:

\begin{tabular}{|c|c|}
\hline Weight & $60,5 \mathrm{Kg}$ \\
\hline Size & $1,78 \mathrm{~m}$ \\
\hline IMC & $19,10 \mathrm{Kg} / \mathrm{m} 2$ \\
\hline CMB & $25 \mathrm{~cm}$ \\
\hline PTr & $5 \mathrm{~mm}$ \\
\hline
\end{tabular}

Medic and Pharmacologically was managed with: 2000cc IV $0.45 \%$ saline solution alternated with $0.9 \%$ saline at $60 \mathrm{cc}$ per/hour; Metronidazol 500mg (IV) (q8h) every 8hours; Ranitidine 50mg (IV) every 8 hours; Ketoprofeno 100 mg (IV) every 8 hours SOS pain; Metaclopramida 10mg (IV) every 8hours SOS N/V. On 03/23/07, the patient is in Good General Conditions (GGCs); no fever, eupeptic, adapted for walking, tolerating oral diet, with functioning colostomy and waiting for surgery. On $03 / 25 / 07$, pre-operative orders include (NPO), and on March 26, 2007 (Figure 2), he is taken to the operation room to undergo Laparotomy for intestinal tract restitution, and at the same time, repair the Colocutaneous Fistula, wherefrom the next findings and procedures featured: On the $1^{\text {st }}$ post-operative day, he is kept NPO (nil per os), refers feeling well but with a slight pain at surgical wound, and passing flatus. The physical examination features HR73bpm; RR17rpm, no fever and well hydrated. Cardio-pulmonary: Stable. Abdomen: Soft, slightly painful, diminished bowel sounds (RsHs+); rest unremarkable. 


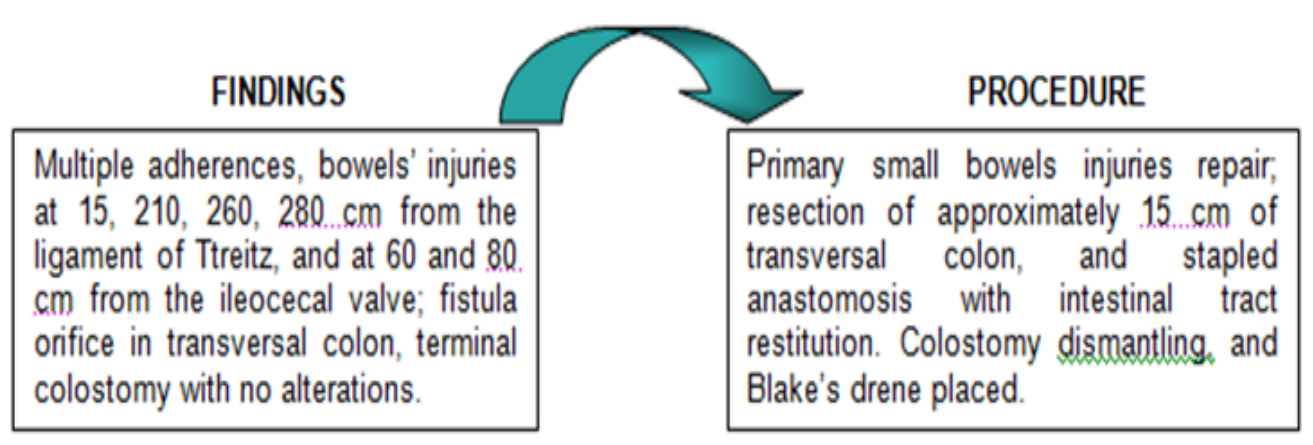

Figure 2.

\section{Observations}

Table 8: Laboratory Values.

\begin{tabular}{|c|c|c|c|}
\hline Parameters & Values & Parameters & Values \\
\hline $\begin{array}{c}\text { HGB n/mm3 x } \\
10.000\end{array}$ & $(13,9)$ & Albumin g/dL & $(4.2$ \\
\hline Hcto Vol \% & $(42,4)$ & Globulins g/dL & $(3.1)$ \\
\hline WBC mm3 & $(5.700)$ & Uric acid mg/dL & - \\
\hline Neutrophyles \% & $(47.5)$ & Cholesterol mg/dL & - \\
\hline Lymphocytes \% & $(36.5)$ & Triglycerides mg/dL & - \\
\hline CTL mm3 & $(2081)$ & $\mathrm{Na}+\mathrm{mmol} / \mathrm{L}$ & $(138)$ \\
\hline PLT $10 \mathrm{~mm} 3$ & $(252)$ & $\mathrm{K}+\mathrm{mmol} / \mathrm{L}$ & $(4.6)$ \\
\hline Glycemia mg/dL & $(105)$ & $\mathrm{Cl}-\mathrm{mmol} / \mathrm{L}$ & $(104)$ \\
\hline Urea mg/dL & $(31)$ & Calcium mg/dL & - \\
\hline Creatinine mg/dL & $(0.77)$ & Phosphor mg/dL & $(7.3)$ \\
\hline Proteins T. g/dL & $(7.3)$ & Magnesium mg/dl & $(1.1)$ \\
\hline
\end{tabular}

Maintains NPO On the $4^{\text {th }}$ PO day (03/30/07), there is evidence of intestinal liquid effusion through the surgical wound, reason for which the diagnosis is "Enterocutaneous Fistula of fast output (675cc in 24h)", subsequently confirmed by Fistulogram. This new fistula is of surgical origin, external, simple, single orifice and of high output (675cc in 24h).0n 03/30/07, the patient is evaluated by the Nutritional Support Unit (NSU) in order to establish nutrition and treatment plan. As for the Subjective Global Valuation (SGV), he is classified B (Moderate Malnutrition) and the following anthropometric data is obtained (Table 8): The Caloric Requirement was calculated employing Harris' and Benedict's Equation for calculating basal metabolism with an 1.2 activity factor, and stress factor of 1.3 , the goal thereof being $2424 \mathrm{Kcal}$ (just one factor). From complementary blood work of 03/29/07, the following was appraised: As nutritional measure is suggested to initiate transitory PPN (Peripheral Parenteral Nutrition) until obtaining central venous access - obtained 5days later - with a hypo-caloric or insufficient contribution of $1151 \mathrm{Kcal}$ (19Kcal/ Kg of current weight) according to the following scheme: Positive findings are corrected (Table 9).

Table 9: Laboratory results of $03 / 18 / 07$, show the following values.

\begin{tabular}{|c|c|}
\hline Weight & $61 \mathrm{Kg}$ \\
\hline Size & $1,78 \mathrm{~m}$ \\
\hline
\end{tabular}

\begin{tabular}{|c|c|}
\hline IMC & $19,30 \mathrm{Kg} / \mathrm{m}^{2}$ \\
\hline CMB & $25 \mathrm{~cm}$ \\
\hline PTr & $5 \mathrm{~mm}$ \\
\hline
\end{tabular}

Medic and Pharmacologically is managed with: 0.9\%HP $2000 \mathrm{cc}$ solution alternated with $0.45 \%$ at $60 \mathrm{cc}$ per/hour; Unasyn IV 3g every 6hours; Amikacina IV $1 \mathrm{~g}$ diluted OD; Metronidazol $500 \mathrm{mg}$ IV every 8 hours; 1Dipirona IV ampoule every 8hours SOS fever; Omeprazol 40mg IV OD; Ketoprofeno 100mg IV every 8hours SOS pain; Metaclopramida 10mg IV every 8hours SOS $\mathrm{n} / \mathrm{v}$, and Nebulization (atomization) with 20drops Berodual + 3cc 0.9 solution every 8hours (Tables 10 \& 11). A transitory via right subclavian TPN with inmunomodulation $(0.4 \mathrm{p} / \mathrm{kg}$ ) was implemented on $04 / 03 / 07$, resulting in an intake of $1321 \mathrm{Kcal}$ (22 Kcal/Kg of current weight) according to the following scheme (Table 12): As of 04/04/07, pharmacologically treatment began with somatostatine (Sandostatina冈) due to the fistula's high output ( $>500 \mathrm{cc} / 24$ hours). On subsequent evaluations, TPN's caloric intake is increased summarizing as follows (Table 13): Reaching nutritional goal on $05 / 08 / 07$ on day 7 th of no fistula output, Liquid Diet is administered (600Kcal) keeping the TPN goal requirement (2424Kcal). On the following day (05/16/07), the patient tolerates oral feeding with no fistula output, for which reason diet is advanced further to Full Liquid Diet (1200 Kcal) reducing in 50\% the TPN's contribution, to receive a total caloric intake of $2412 \mathrm{Kcal} /$ day ( 40 VKcal/day) (Table 14). On 05/19/07, the patient still tolerates oral feeding, and a Soft Diet is indicated (1800 Kcal) supplemented with (500Kcal) polymeric formula, as well as orders given for the central catheter's removal, for which that moment's caloric intake was in $2300 \mathrm{Kcal} /$ day (38Kcal/Kg current weight) with a weight gain of $2.3 \mathrm{Kg}$ as from TPN's start, up to its discontinuation.

Table 10: Figures in red: above normal values Figures in yellow: below normal values.

\begin{tabular}{|c|c|c|c|}
\hline Parameters & Values & Parameters & Values \\
\hline $\begin{array}{c}\text { HGB n/mm3 x } \\
10.000\end{array}$ & $(12,7)$ & Albumin g/dL & $(4.4)$ \\
\hline Hcto Vol \% & $(38,9)$ & Globulins g/dL & $(3,1)$ \\
\hline WBC mm3 & $(8.100)$ & Uric acid mg/dL & - \\
\hline Neutrophyles \% & $(90,7)$ & Cholesterol mg/dL & - \\
\hline Lymphocytes \% & $(5,7)$ & $\begin{array}{c}\text { Triglycerides mg/ } \\
\mathrm{dL}\end{array}$ & - \\
\hline CTL mm3 & $(462)$ & $\mathrm{Na}+\mathrm{mmol} / \mathrm{L}$ & $(139)$ \\
\hline
\end{tabular}




\begin{tabular}{|c|c|c|c|}
\hline PLT $10 \mathrm{~mm} 3$ & $(278)$ & $\mathrm{K}+\mathrm{mmol} / \mathrm{L}$ & $(4,1)$ \\
\hline Glycemia $\mathrm{mg} / \mathrm{dL}$ & $(108)$ & $\mathrm{Cl}-\mathrm{mmol} / \mathrm{L}$ & $(108)$ \\
\hline Urea $\mathrm{mg} / \mathrm{dL}$ & $(52)$ & Calcium mg/dL & - \\
\hline Creatinine mg/dL & $(1,13)$ & Phosphor mg/dL & - \\
\hline Proteins $\mathrm{T} . \mathrm{g} / \mathrm{dL}$ & $(7.5)$ & Magnesium mg/dl & - \\
\hline
\end{tabular}

Table 11: From the patient's nutritional evaluation performed on 04/03/07, the following anthropometric data is obtained:

\begin{tabular}{|c|c|}
\hline Kcal & $1151(19 \mathrm{Kcal} / \mathrm{Kg})$ \\
\hline Proteins & $1,5 / 93 / 372$ \\
\hline Fats & $0,8 / 49 / 439$ \\
\hline CHO & $1,6 / 100 / 340$ \\
\hline AA $8,5 \%$ & $1094 \mathrm{cc}-93 \mathrm{~g}$ \\
\hline Lipid $20 \%$ & $245 \mathrm{cc}-49 \mathrm{~g}$ \\
\hline Dext $10 \%$ & $1000 \mathrm{cc}-100 \mathrm{~g}$ \\
\hline NaCl $20 \%$ & $18 \mathrm{cc}-61 \mathrm{mEq}(1)$ \\
\hline KCl 7,5\% & $48 \mathrm{cc}-48 \mathrm{mEq}(0,8)$ \\
\hline Phosphor K $13,5 \%$ & $23 \mathrm{cc}-23 \mathrm{mEq}(20)$ \\
\hline MgSO4 50\% & $7 \mathrm{cc}-29 \mathrm{mEq}(0,47)$ \\
\hline Gluc Ca $10 \%$ & $11 \mathrm{cc}-5 \mathrm{mEq}$ \\
\hline Trazel & $2 \mathrm{cc}$ \\
\hline Folic acid & $1 \mathrm{cc}$ \\
\hline Benutrex & $1 \mathrm{cc}$ \\
\hline Vitamin C & $5 \mathrm{cc}$ \\
\hline cc Total & 2455 \\
\hline cc Hour & 102 \\
\hline Drops/min & $34 \mathrm{x}$ \\
\hline cc/Kg & 40 \\
\hline The & \\
\hline
\end{tabular}

Table 12: The next results highlighted from laboratory values of 04/02/07.

\begin{tabular}{|c|c|}
\hline Weight & $58 \mathrm{Kg}$ \\
\hline Size & $1,78 \mathrm{~m}$ \\
\hline IMC & $18,35 \mathrm{Kg} / \mathrm{m} 2$ \\
\hline CMB & $24 \mathrm{~cm}$ \\
\hline PTr & $4 \mathrm{~mm}$ \\
\hline
\end{tabular}

Table 13: Figures in red: above normal values, Figures in yellow: below normal values.

\begin{tabular}{|c|c|c|c|}
\hline PARAMETERS & VALUES & PARAMETERS & VALUES \\
\hline $\begin{array}{c}\text { HGB } \mathrm{n} / \mathrm{mm} 3 \mathrm{x} \\
10.000\end{array}$ & $(9.4)$ & Albumin g/dL & $(2.2)$ \\
\hline Hcto Vol \% & $(28.1)$ & Globulins g/dL & $(3.8)$ \\
\hline WBC $\mathrm{mm} 3$ & $(16.200)$ & Uric acid mg/dL & - \\
\hline Neutrophyles \% & $(82)$ & Cholesterol $\mathrm{mg} / \mathrm{dL}$ & $(67)$ \\
\hline Lymphocytes \% & $(8.5)$ & Triglycerides $\mathrm{mg} / \mathrm{dL}$ & $(301)$ \\
\hline CTL mm3 & $(1377)$ & $\mathrm{Na}+\mathrm{mmol} / \mathrm{L}$ & $(146)$ \\
\hline PLT $10 \mathrm{~mm} 3$ & $(153)$ & $\mathrm{K}+\mathrm{mmol} / \mathrm{L}$ & $(4)$ \\
\hline Glycemia $\mathrm{mg} / \mathrm{dL}$ & $(99)$ & $\mathrm{Cl}-\mathrm{mmol} / \mathrm{L}$ & $(111)$ \\
\hline Urea $\mathrm{mg} / \mathrm{dL}$ & $(28)$ & $\mathrm{Calcium} \mathrm{mg/dL}$ & $(7.6)$ \\
\hline
\end{tabular}

\begin{tabular}{|c|c|c|c|}
\hline (corrected 8.8) & & & \\
\hline Creatinine mg/dL & $(0.59)$ & Phosphor mg/dL & $(3.5)$ \\
\hline Proteins T. g/dL & $(6.0)$ & Magnesium mg/dl & - \\
\hline
\end{tabular}

Table 14: As of 04/04/07, pharmacologically treatment began with somatostatine (Sandostatina布 due to the fistula's high output (>500 cc/24 hours).

\begin{tabular}{|c|c|}
\hline Kcal & 1321 (22 Kcal/Kg) \\
\hline Proteins & $1,5 / 93$ / 372 \\
\hline Fats & $0,8 / 49 / 439$ \\
\hline $\mathrm{CHO}$ & $2,4 / 150 / 510$ \\
\hline AA $8,5 \%$ & $1094 c c-93 g$ \\
\hline Lipid 20\% & $245 c c-49 g$ \\
\hline Dext $10 \%$ & $300 \mathrm{cc}-150 \mathrm{~g}(50 \%)$ \\
\hline $\mathrm{NaCl} 20 \%$ & $18 \mathrm{cc}-61 \mathrm{mEq}(1)$ \\
\hline $\mathrm{KCl} 7,5 \%$ & $48 \mathrm{cc}-48 \mathrm{mEq}(0,8)$ \\
\hline Phosphor K 13,5\% & $23 \mathrm{cc}-23 \mathrm{mEq}(20)$ \\
\hline $\mathrm{MgSO} 450 \%$ & $5 c c-21 \mathrm{mEq}(0,34)$ \\
\hline Gluc Ca $10 \%$ & $11 \mathrm{cc}-5 \mathrm{mEq}$ \\
\hline Trazel & $2 \mathrm{cc}$ \\
\hline Folic acid & $1 \mathrm{cc}$ \\
\hline Benutrex & $1 \mathrm{cc}$ \\
\hline Vit C & $5 c c$ \\
\hline cc Total & 1753 \\
\hline cc Hour & 73 \\
\hline Drops/min & $24 \mathrm{x}^{\prime}$ \\
\hline $\mathrm{cc} / \mathrm{Kg}$ & 29 \\
\hline
\end{tabular}

Throughout the patient's progress, all that outlined in Sheldon's stages was fulfilled for managing fistulas, correcting hydro electrolytic alterations by means of, namely: parenteral hydration and parenteral nutritional support; the antibiotics and somatostatine therapy for reducing fistula output and keep an ulcer-less skin, combining it with the TPN timely handling; and in this manner, achieve nutritional status recuperation and the spontaneous enterocutaneous fistula's closure in a 40days-time upon diagnoses.

Next, the patient's enterocutaneous fistula's output is graphically featured, as well as its connection with (PPN \& TPN) nutritional support and somatostatine administering (Figure 3). For better apprehension, the patient's evaluation of leucocytes and plasmatic glycemia at laboratory level values during his hospitalization is next graphically displayed (Figure 4): As to anthropometrics, summarizing, the following chart features the anthropometric variables' evolution taken as reference from the patient's nutritional evaluations (Figure 5): Kg: kilogram; m: meters; cm: centimeters; mm: millimeters; IMC: Corporal Mass Index; CMBD: Right Arm Average Circumference; Ptr: Triceps Folding; AG: Fat Area; AM: Poor Area; AM and AG, according to Frisancho's 1993 (Tables 15 \& 16). 


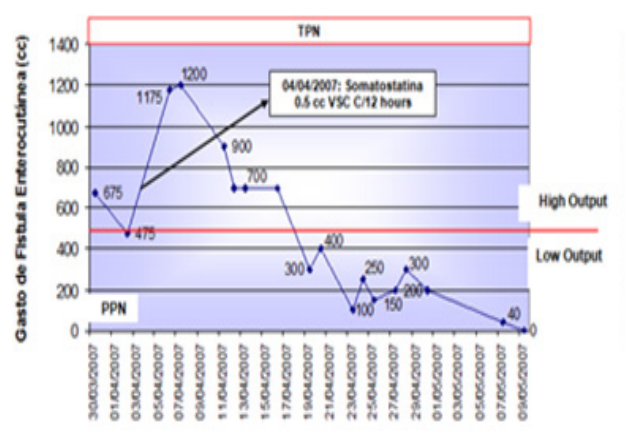

A

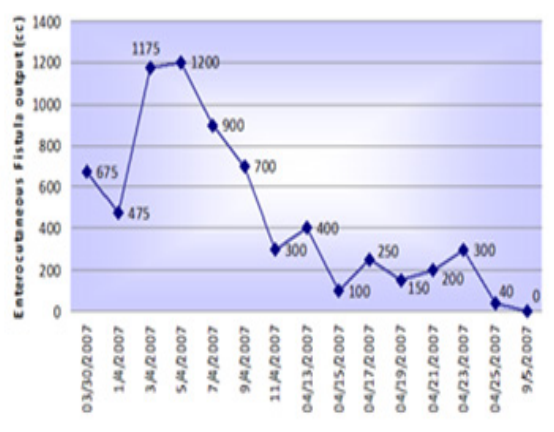

B

Figure 3: Enterocutaneous Fistula Output Evolution and Its Connection with Nutritional Support - Therapy and Somatostatina.

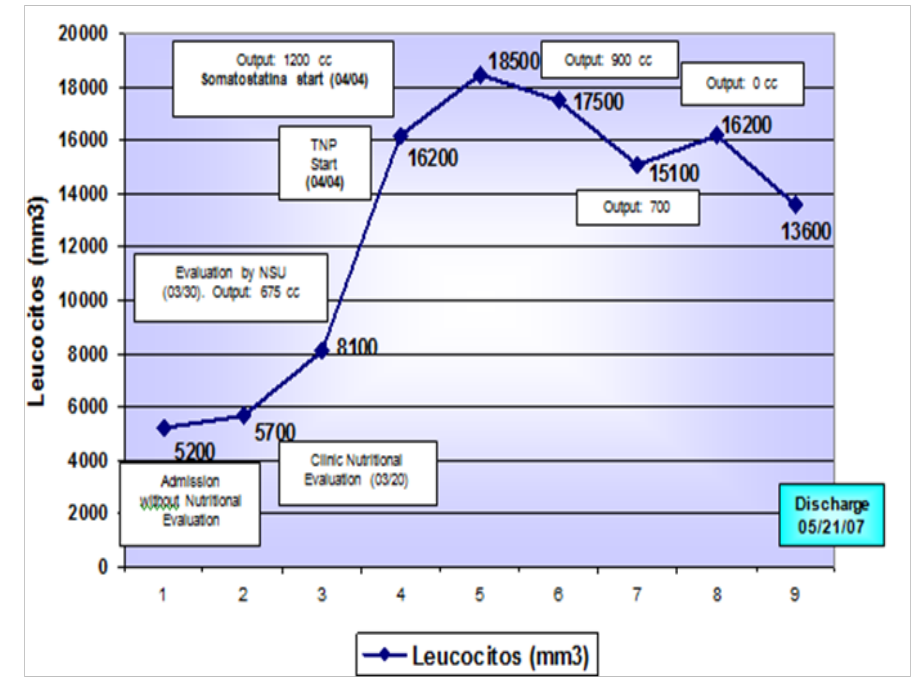

Figure 4: Pacient's Leucocytes And Glicemia Evolution March-May 2007

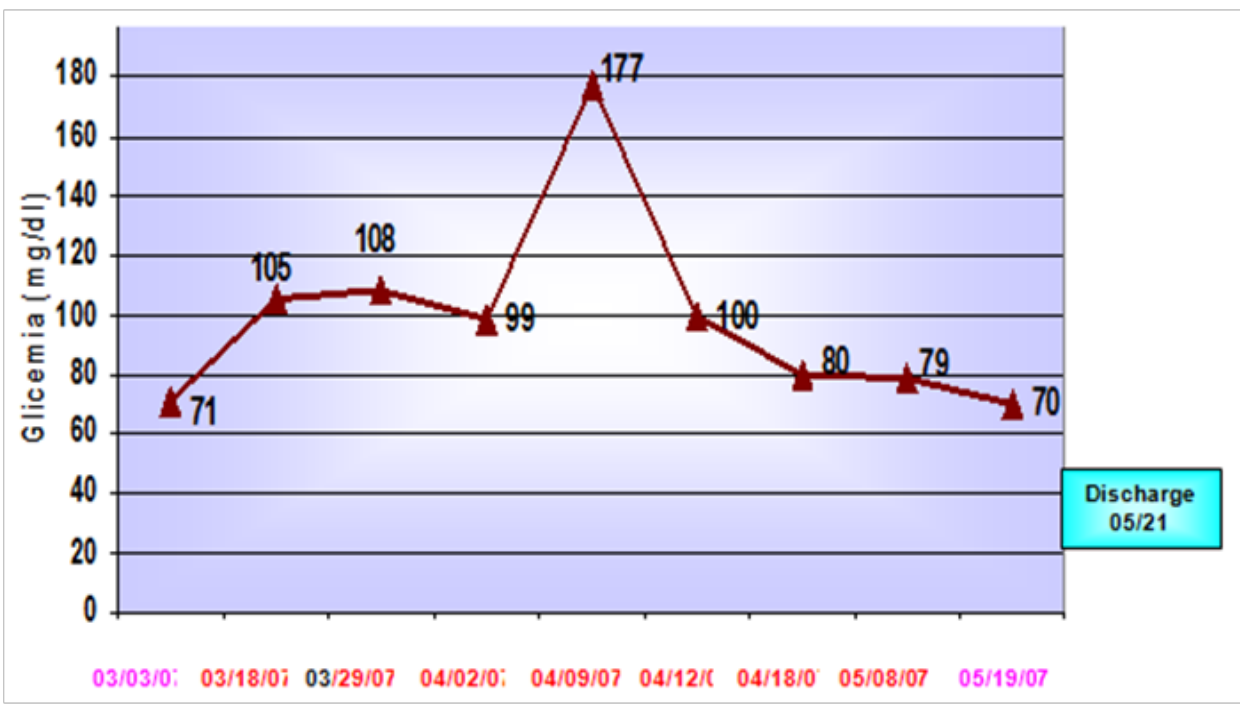

Figure 5: As to anthropometrics, summarizing, the following chart features the anthropometric variables' evolution taken as reference from the patient's nutritional evaluations. 
Table 15: On subsequent evaluations, TPN's caloric intake is increased summarizing as follows.

\begin{tabular}{|c|c|c|c|}
\hline Date & TPN Kcal & Current Weight $\mathbf{~ K g ) ~}$ & Kcal/Kg PA \\
\hline $04 / 12 / 2007$ & 1771 & 58.5 & 30 \\
\hline $04 / 18 / 2007$ & 2049 & 59.1 & 35 \\
\hline $05 / 02 / 2007$ & 2067 & 59.5 & 35 \\
\hline $05 / 08 / 2007$ & 2424 & 60 & 42 \\
\hline
\end{tabular}

Table 16: Reaching nutritional goal on 05/08/07 in complementary laboratory results of $05 / 19 / 07$, a remarkable leucocytosis decrease is evidenced. Figures in red: above normal values, Figures in yellow: below normal values.

\begin{tabular}{|c|c|c|c|}
\hline PARAMETERS & VALUES & PARAMETERS & VALUES \\
\hline $\begin{array}{c}\text { HGB } \mathrm{n} / \mathrm{mm} 3 \mathrm{x} \\
10.000\end{array}$ & $(10.4)$ & Albumin g/Dl & $(3.6)$ \\
\hline Hcto Vol \% & $(31.4)$ & Globulins g/dL & $(3.5)$ \\
\hline WBC mm3 & $(13.600)$ & Uric acid $\mathrm{mg} / \mathrm{dL}$ & $(2.1)$ \\
\hline Neutrophyles \% & $(46.5)$ & Cholesterol $\mathrm{mg} / \mathrm{dL}$ & $(128)$ \\
\hline Lymphocytes \% & $(22.1)$ & Triglycerides mg/dL & $(232)$ \\
\hline CTL mm3 & $(3006)$ & $\mathrm{Na}+\mathrm{mmol} / \mathrm{L}$ & $(139)$ \\
\hline PLT $10 \mathrm{~mm} 3$ & $(726)$ & $\mathrm{K}+\mathrm{mmol} / \mathrm{L}$ & $(5.0)$ \\
\hline Glycemia $\mathrm{mg} / \mathrm{dL}$ & $(70)$ & $\mathrm{Cl}-\mathrm{mmol} / \mathrm{L}$ & $(110)$ \\
\hline Urea $\mathrm{mg} / \mathrm{dL}$ & $(17)$ & $\mathrm{Calcium} \mathrm{mg/dL}$ & - \\
\hline
\end{tabular}

\begin{tabular}{|c|c|c|c|}
\hline Creatinine mg/dL & $(0.74$ & Phosphor mg/dL & - \\
\hline Proteins T. g/dL & $(7.1)$ & Magnesium mg/dl & - \\
\hline
\end{tabular}

As it may be observed from the information referred to on the foregoing chart, the patient's weight depletion went progressively on in the presence of a non-functional GI tract- due to the high output fistula's worsening - and no distally placed catheters. It is possible to observe, however, that subsequently once TPN is initiated, this evidently allowed a larger caloric and protein intake, contributing to the patient's weight gain and improving anabolic condition, up to the moment -given the fistula's previous spontaneous closureTPN is definitively stopped $(05 / 19 / 07)$, all of which highlights the importance of nutritional support in the preservation and upgrading of the intestinal fistula patients' nutritional status, even more if the consideration is made as to that in this patient's case, oral feeding began on 05/09/07 with a proof liquid diet. Plasmatic albumin levels increased progressively as and how featured on the next graphic (Figure 6). The graphic shows that there is a directly proportional connection between plasmatic albumin and corporal weight levels, being thus evidenced that in the extent the patient's corporal weight increases or decreases, so also do albumin values. With respect to the TPN caloric intake, as it increases towards the caloric requirement goal, so also did the patient's corporal weight, reaching a top of $59.5 \mathrm{Kg}$ associated to the TPN goal for $05 / 08 / 07$.

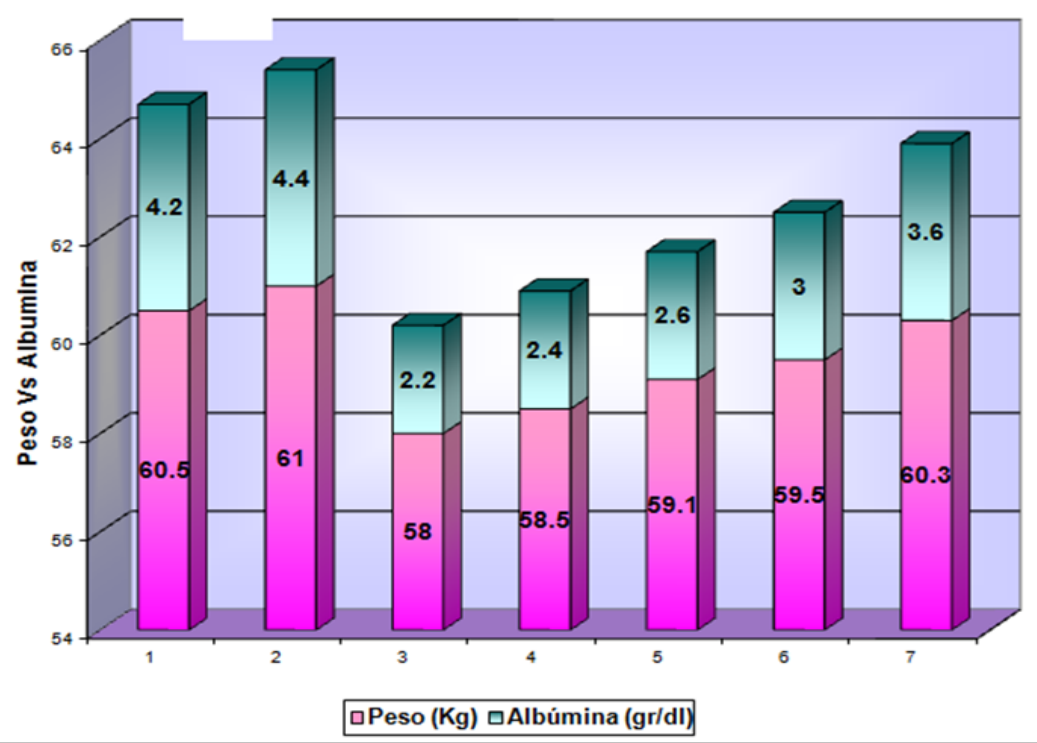

Figure 6: Connection between Patient's Corporal weight Evolution and Plasmatic Albumin Values March-May2007.

Table 17: Patient's anthropometric variables evolution as of 03/20/07 Up to 05/19/07.

\begin{tabular}{|c|c|c|c|c|c|c|c|}
\hline Anthropometry* & $\mathbf{0 3 / 2 0 / 2 0 0 7}$ & $\mathbf{0 3 / 3 0 / 2 0 0 7}$ & $\mathbf{0 4 / 0 3 / 2 0 0 7}$ & $\mathbf{0 4 / 1 2 / 2 0 0 7}$ & $\mathbf{0 4 / 1 8 / 2 0 0 7}$ & $\mathbf{0 5 / 0 2 / 2 0 0 7}$ & $\mathbf{0 5 / 1 9 / 2 0 0 7}$ \\
\hline Weight (Kg) & 60.5 & 61 & 58 & 58.5 & 59.1 & 59.5 & 60.3 \\
\hline Size (m) & 1.78 & 1.78 & 1.78 & 1.78 & 1.78 & 1.78 & 1.78 \\
\hline IMC (Kg/m $\left.{ }^{2}\right)$ & 19.10 & 19.30 & 18.35 & 18.46 & 18.65 & 18.77 & 19.03 \\
\hline CMBD (cm) & 25 & 25.3 & 24 & 24 & 24.6 & 24.8 & 25 \\
\hline Ptr (mm) & 5 & 5.4 & 4 & 4 & 4.6 & 4.6 & 5.2 \\
\hline
\end{tabular}




\begin{tabular}{|c|c|c|c|c|c|c|c|}
\hline $\mathrm{AG}\left(\mathrm{cm}^{2}\right)$ & $5.47(<\mathrm{p} 5)$ & 6.61 p10) & $(<\mathrm{p} 5)$ & $(<\mathrm{p} 5)$ & $(<\mathrm{p} 5)$ & $(<\mathrm{p} 5)$ & $\begin{array}{l}6.29 \\
(<\mathrm{p} 5)\end{array}$ \\
\hline $\mathrm{AM}\left(\mathrm{cm}^{2}\right)$ & $\begin{array}{c}43.66 \\
(p 10-p 15)\end{array}$ & $\begin{array}{c}44.31 \\
(\mathrm{p} 10-\mathrm{p} 15)\end{array}$ & $\begin{array}{l}41.15 \\
(<\mathrm{p} 5)\end{array}$ & $\begin{array}{l}41.15 \\
(<\mathrm{p} 5)\end{array}$ & $\begin{array}{c}42.65 \\
(\mathrm{p} 10-\mathrm{p} 15)\end{array}$ & $\begin{array}{c}43.39 \\
(\mathrm{p} 10-\mathrm{p} 15)\end{array}$ & $\begin{array}{c}43.43 \\
\text { (p10-p15) }\end{array}$ \\
\hline
\end{tabular}

Thereafter, the nutritional support -therapy weaning takes place in function of the patient's oral tolerance, notwithstanding that corporal weight continues to increase thanks to the combination of TPN and oral feeding up to $05 / 19 / 07$, when IV is definitively suspended, leading to the patient's discharge on 05/21/07 for presenting zero fistula output, and full oral diet tolerance, easier to appreciate on the following graphic (Figure 7): Given the significant recovery/improvement at metabolic and anthropometric level, toleration of oral feeding, in addition to 12 days of no enterocutaneous fistula output, with a hydration balance of +200 , and a nitrogen balance of +4 , the patient is then discharge on May 21, 2007. Discharge Diet: Hyper-caloric 2,300Kcal; high
proteins/Kg weight intake, distributed in 3 main meals, and 2 afternoon-snacks. "Finally, it has been confirmed that fistula patients' management is a complex one; it needs the close discussion between both, the responsible surgical and nutritional therapy teams. The most important fact in fistula cases is preventing them to happen. Surgeons should always bear in mind the disadvantages of operating undernourished patients [11] as said Kumpf VJ, de Aguilar-Nascimento. Malnutrition is often the main cause of postoperative fistulas occurrence, and therefore, these patients should be previously evaluated and undergo a peri-operative nutritional therapy" Baptista G.

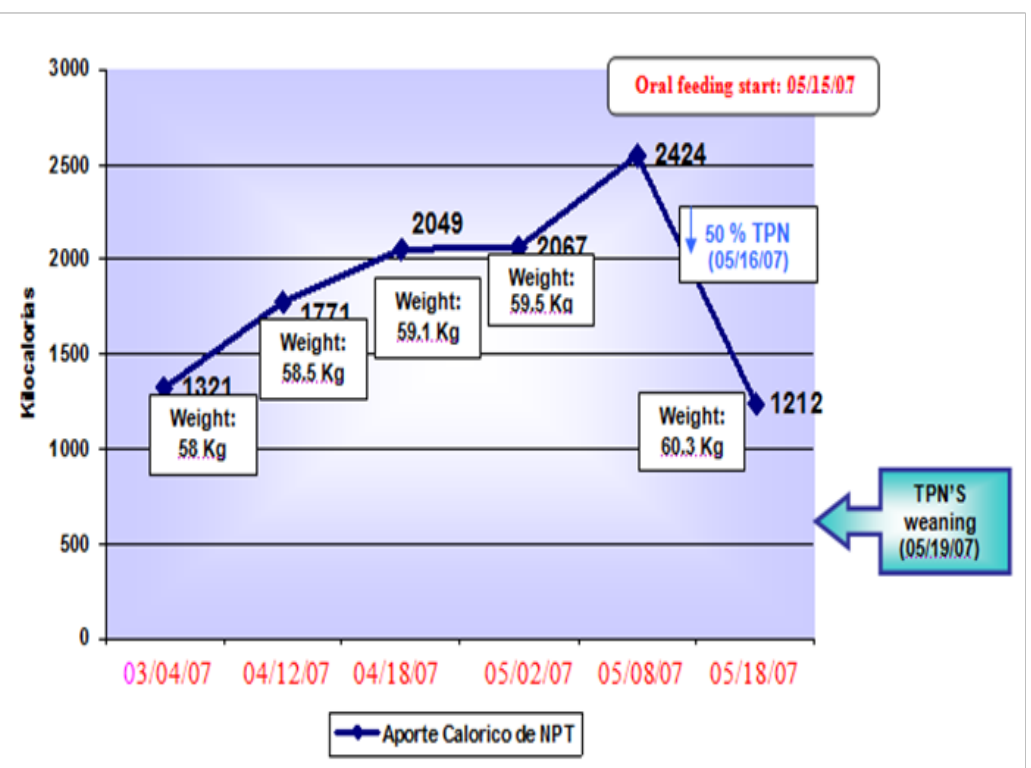

Figure 7: Connection between Patient's Corporal Weight, Oral Diet and Tpn Caloric Contribution April - May 2007.

\section{References}

1. Chapman R, Foran R, Dunphy JE (1964) Management of intestinal Fistulas. Am J Surg 108: 157-164.

2. Belloso R, Souchon E, Adrianza Baptista G, Benaim V, Ayala L (1999) Efectividad en el tratamiento de las fístulas: 21 años de experiencia en la Unidad de Soporte Nutricional. Clin Med 4: 75-83.

3. Ellis, Harold (1996) Operations that Made History. Cambridge University Press, Cambridge, USA.

4. Fukuchi S (1998) Nutritional support of patients with enterocutaneous fistulas. Nutr Clin Pract 13(2): 59.

5. Rombeau J, Caldwell M (1986) Clinical nutrition: parenteral nutrition. Saunders, Philadelphia, USA pp. 426.

6. Tulsyan N, Abkin A, Storch KJ (2001) Enterocutaneous fistulas. Nutr Clin Pract 16(2): 74-77.
7. Sheldon GF, Gardiner BN, Way LW, Dunphy JE (1971) Management of gastrointestinal fistulas. Surg Gynecol Obstet 133: 385-389.

8. Alvarez C, McFadden DW, Reber HA (2000) Complicated enterocutaneous fistulas: failure of octreotide to improve healing World J Surg 24(5): 533537.

9. Nubiola P, Badia JM, Martinez-Rodenas F, Gil MJ, Segura M, et al. (1989) Treatment of 27 postoperative enterocutaneous fistulas with the long half-life somatostatin analogue SMS 201-995. Ann Surg 210(1): 56-58.

10. Schwartz D, Wiersema M, Dudiak K (2001) Comparison of endoscopic ultrasound, magnetic resonance imaging and exam under anesthesia for evaluation of Chron's perianal fistulas. Gastroenterology 121: 10641072.

11. José Eduardo Aguilar-Nascimento Jose Ignacio Diaz-Pizarro Graf • Charlene Compher ASPEN-FELANPE Clinical Guidelines: Nutrition Support of Adult Patients With Enterocutaneous Fistula Journal of Parenteral and Enteral Nutrition 41(1) · December 2016 
(c) This work is licensed under Creative

Submission Link: https://biomedres.us/submit-manuscript.php

Assets of Publishing with us
BIOMEDICAL
RESEARCHES
- Global archiving of articles
Immediate, unrestricted online access
ISSN: 2574-1241

